\title{
Determination of the Feed Value of Wheat Straw: Turkey, Siirt Province Case
}

\author{
Semih Acikbas (Corresponding author) \\ Siirt University, Faculty of Agriculture, Department of Field Crops, Siirt, Turkey \\ E-mail: semihacikbas@siirt.edu.tr \\ Mehmet Arif Ozyazici \\ Siirt University, Faculty of Agriculture, Department of Field Crops, Siirt, Turkey \\ E-mail: arifozyazici@siirt.edu.tr
}

\begin{abstract}
In this research, it was aimed to determine the feed value of wheat straw commonly used in animal nutrition. For this purpose, a total of 25 wheat (Triticum aestivum L.) straw samples were collected from the wheat production areas in Siirt province in the Southeastern Anatolia region of Turkey. In the samples, acid detergent insoluble fiber (ADF) ratio, neutral detergent insoluble fiber (NDF) ratio, crude protein (HP) ratio, phosphorus $(\mathrm{P})$, potassium $(\mathrm{K})$, calcium $(\mathrm{Ca})$ and magnesium $(\mathrm{Mg})$ analyzes were performed. As a result of the research $\mathrm{ADF}, \mathrm{NDF}, \mathrm{CP}, \mathrm{P}, \mathrm{K}, \mathrm{Ca}$ and $\mathrm{Mg}$ ratios of wheat straw dry matter ranged between $46.29-58.69 \%, 75.88-89.30 \%, 0.24-5.03 \%, 0.08-0.22 \%, 0.12-1.52 \%, 0.10-0.58 \%$, and $0.02-$ $0.27 \%$, respectively. According to the results, it was found that the feed value of wheat straw was low.
\end{abstract}

Keywords: Triticum aestivum L., Crude protein, Phosphorus, Potassium, Calcium, Magnesium.

DOI: $10.7176 / \mathrm{JSTR} / 5-12-25$

\section{Buğday Samanının Yem Değerinin Belirlenmesi: Türkiye, Siirt İli Örneği}

Özet

$\mathrm{Bu}$ çalışmada, hayvan beslenmesinde yaygın olarak kullanılan buğday samanının yem değerinin belirlenmesi amaçlanmıştır. Bu amaca yönelik olarak, Türkiye'nin Güneydoğu Anadolu Bölgesi'nde yer alan Siirt ilinde, buğday üretimi yapılan alanlardan toplam 25 adet buğday (Triticum aestivum L.) samanı örneği alınmıştır. Alınan örneklerde, asit deterjanda çözünmeyen lif (ADF) oranı, nötral deterjanda çözünmeyen lif (NDF) oranı, ham protein (HP) oranı, fosfor (P), potasyum (K), kalsiyum (Ca) ve magnezyum $(\mathrm{Mg})$ analizleri yapılmıştır. Araştırma sonucunda buğday samanı kuru maddesindeki ADF, NDF, HP, P, K, Ca ve Mg oranlarının sirasiyla \% 46.29-58.69, \% 75.88-89.30, \% 0.24-5.03, \% 0.08$0.22, \% 0.12-1.52, \% 0.10-0.58$ ve \% 0.02-0.27 arasında değişim gösterdiği belirlenmiştir. Elde edilen sonuçlara göre buğday samanının yem değerinin düşük olduğu belirlenmiştir.

Anahtar Kelimeler: Triticum aestivum L., Ham protein, Fosfor, Potasyum, Kalsiyum, Magnezyum.

\section{Giriş}

Türkiye'de kaliteli kaba yem kaynaklarının başında, doğal çayır mera alanları ve tarla tarımı içerisinde ekilişi yapılan yem bitkileri gelmektedir. Doğal çayır mera alanlarının amenajman ilkelerine uyulmadan sevk ve idaresinin yapılması sonucunda, bu alanların yem üretim potansiyellerini büyük oranda kaybetmiş durumda olmaları, tarla tarımı içerisindeki yem bitkisi ekiliş oranının henüz istenilen düzeyde olmaması gibi nedenlerden dolayı Türkiye'de üretilen kaba yemler mevcut hayvan varlığının ihtiyacını karşılayamamaktadır. Bu durum birçok araştırmacı (Güngör ve ark., 2008; Kuşvuran ve ark., 2011; Özkan ve Şahin Demirbağ, 2016; Bıçakçı ve Açıkbaş, 2018) tarafından da rapor edilmiştir. Bu nedenle, çayır mera ve yem bitkileri tarımından elde edilen kaba yemler dışında, serin iklim tahıllarından elde edilen sap-saman gibi harman kalıntıları, Türkiye genelinde çiftçilerimiz tarafindan hayvansal üretimde kaba yem kaynağı olarak tercih edilmektedir.

Öte yandan, Türkiye'de üretilen samanın büyük bir bölümünü buğday samanı teşkil etmekte, 2018 y1lı verilerine göre de yaklaşık 20 milyon ton buğday samanı [dane:saman oranı 1:1 dikkate alındığında, 
Kalkan ve Filya (2011)] üretilmektedir (Anonim, 2019). Ancak samanların, genel olarak düşük proteinli olması, yüksek oranda ham selüloz, lignin ve hemiselüloz içermesi dolayısıyla sindirilebilirliklerinin de düşük olması (Jeroch ve ark., 1993; Abdi ve Kılıç, 2018) nedeniyle hayvanlara sadece tokluk hissi verdiği bilinmektedir. Bununla birlikte hayvanların dengeli bir biçimde beslenmeleri için, yemlerin yapısında bulunan besin maddeleri düzeylerinin bilinmesi gerekmektedir.

$\mathrm{Bu}$ çalışmada, Siirt ilinde üretilen ve hayvan beslenmesinde yaygın olarak kullanılan buğday samanının yem değerinin belirlenmesi amaçlanmıştır.

\section{Materyal ve Yöntem}

Araştırmanın materyalini; Türkiye'nin Güneydoğu Anadolu Bölgesi'nde yer alan Siirt ilinde, buğday üretimi yapılan alanlardan (Şekil 1) alınan 25 adet buğday (Triticum aestivum L.) samanı örnekleri oluşturmaktadır.

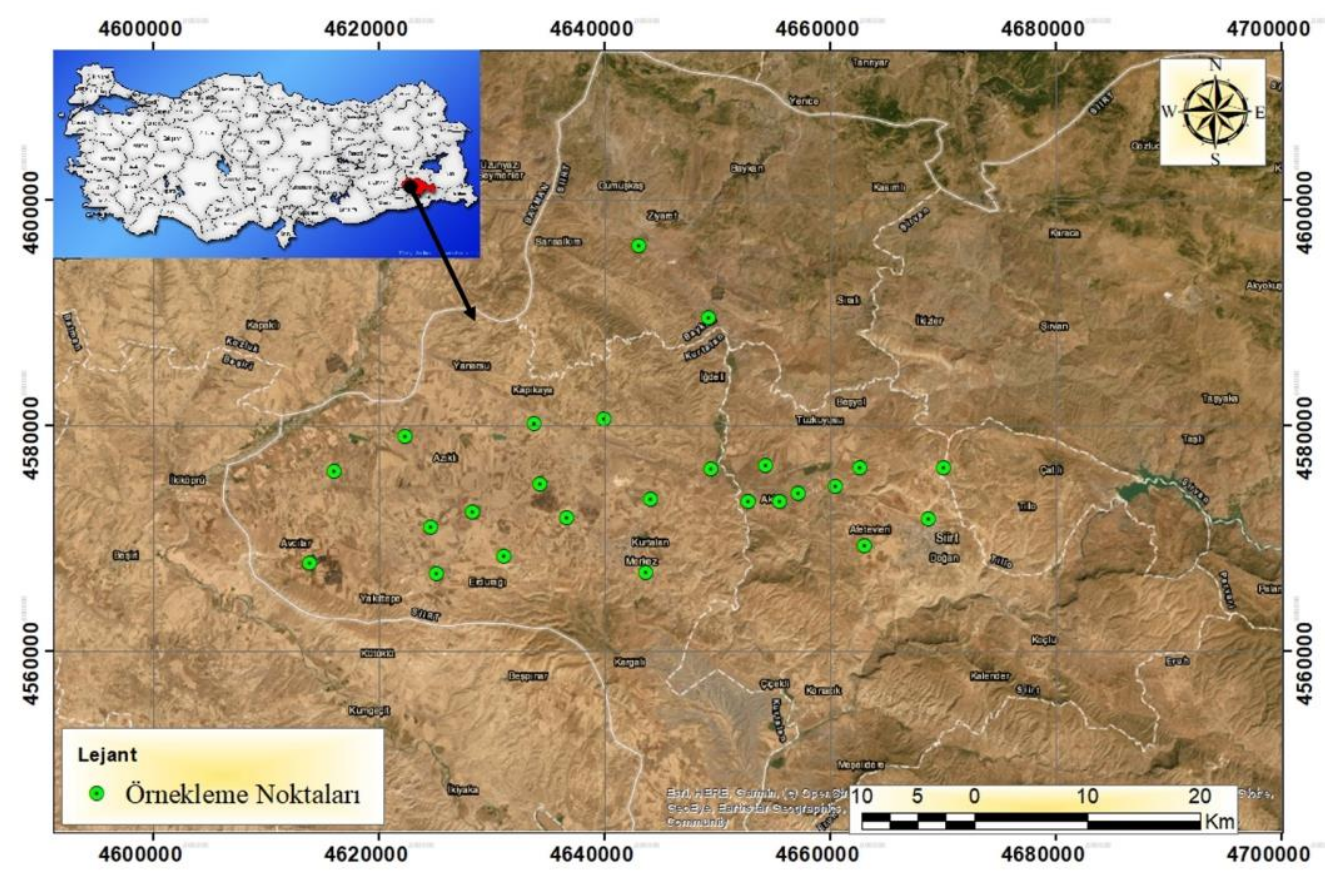

Şekil 1. Saman örnekleme noktaları

Saman örnekleri, buğday üretiminin yoğun olduğu alanlardan, mevcut üretim alanlarını temsil edecek şekilde tesadüfi olarak 2019 yılı Temmuz ayında alınmıştır. Örnekleme yapılan üretim alanlarına ait yer koordinat bilgileri Tablo 1'de verilmiştir.

Toplanan saman örnekleri öğüülerek analize hazır hale getirilmiştir. Buğday samanı kaba yem maddesinin bazı besin maddesi içeriklerini belirlemek amacıyla örneklerde; asit deterjanda çözünmeyen lif (ADF), nötral deterjanda çözünmeyen lif (NDF), ham protein (HP), fosfor (P), potasyum (K), kalsiyum (Ca) ve magnezyum $(\mathrm{Mg})$ analizleri yapılmıştır. Adı geçen bu analizler; Ondokuz Mayıs Üniversitesi Ziraat Fakültesi Tarla Bitkileri Bölümü Laboratuvarı'nda, NIRS (Near Infrared Reflektance Spectroscopy-Yakın Kızıl Ötesi Yansıması Spektroskopisi) cihazı ile \#IC-0904FE kalibrasyon seti (Anonymous, 2018) kullanılarak belirlenmiştir (Brogna ve ark., 2009).

Buğday samanı kuru maddesinde belirlenen ADF, NDF ve HP değerlerine göre kaba yemin kalite derecesinin değerlendirilmesinde, Rohweder ve ark. (1978) tarafindan sinıflandırılan Tablo 2'deki değerler kullanılmıştır. 
Tablo 1. Saman örnekleme noktalarına ait yer ve koordinat bilgileri

\begin{tabular}{ccccl}
\hline No & Enlem & Boylam & Rakım $(\mathrm{m})$ & Yer/Mevki \\
\hline 1 & $37.946277^{\circ}$ & $41.940470^{\circ}$ & 861 & Siirt-Merkez \\
2 & $37.962595^{\circ}$ & $41.836149^{\circ}$ & 618 & Siirt-Merkez \\
3 & $37.978044^{\circ}$ & $41.767445^{\circ}$ & 541 & Siirt-Bitlis yolu üzeri \\
4 & $38.072470^{\circ}$ & $41.765121^{\circ}$ & 614 & Baykan-Çaykaya köyü \\
5 & $38.117903^{\circ}$ & $41.709600^{\circ}$ & 711 & Baykan-Ziyaret beldesi \\
6 & $37.959001^{\circ}$ & $41.718769^{\circ}$ & 807 & Kurtalan-Oyac1k köyü \\
7 & $38.008879^{\circ}$ & $41.681615^{\circ}$ & 887 & Kurtalan-Bölüktepe köyü \\
8 & $37.978823^{\circ}$ & $41.952431^{\circ}$ & 1044 & Tillo-İkizbağlar köyü \\
9 & $37.946829^{\circ}$ & $41.652224^{\circ}$ & 741 & Kurtalan-Gürgöze köyü \\
10 & $37.967886^{\circ}$ & $41.630825^{\circ}$ & 744 & Kurtalan-Kayabağlar köyü \\
11 & $37.923242^{\circ}$ & $41.602460^{\circ}$ & 816 & Kurtalan-Kaynaklı köyü \\
12 & $37.950667^{\circ}$ & $41.576881^{\circ}$ & 691 & Kurtalan-Güzeldere köyü \\
13 & $37.957140^{\circ}$ & $41.796875^{\circ}$ & 603 & Merkez-Aktaş köyü \\
14 & $37.911823^{\circ}$ & $41.548094^{\circ}$ & 745 & Kurtalan-Şenköy \\
15 & $37.980169^{\circ}$ & $41.810314^{\circ}$ & 621 & Merkez-P1narova köyü \\
16 & $37.941528^{\circ}$ & $41.543734^{\circ}$ & 775 & Kurtalan-Demirkuyu köyü \\
17 & $37.912596^{\circ}$ & $41.715109^{\circ}$ & 736 & Kurtalan-Merkez \\
18 & $37.957621^{\circ}$ & $41.821812^{\circ}$ & 610 & Merkez-Aktaş köyü \\
19 & $37.998423^{\circ}$ & $41.523698^{\circ}$ & 663 & Kurtalan-Saipbeyli köyü \\
20 & $37.976379^{\circ}$ & $41.467070^{\circ}$ & 715 & Kurtalan-Gözpınar köyü \\
21 & $37.929519^{\circ}$ & $41.889598^{\circ}$ & 809 & Siirt-Merkez \\
22 & $37.918273^{\circ}$ & $41.447731^{\circ}$ & 771 & Kurtalan-Avcılar köyü \\
23 & $37.978168^{\circ}$ & $41.885736^{\circ}$ & 755 & Merkez-Ïnkap1 köyü \\
24 & $37.967139^{\circ}$ & $41.866209^{\circ}$ & 601 & Merkez-Köprübaş1 köyü \\
25 & $38.006410^{\circ}$ & $41.625881^{\circ}$ & 905 & Kurtalan-Uluköy \\
\hline & & & & \\
\hline
\end{tabular}

Tablo 2. Baklagil, buğdaygil ve baklagil-buğdaygil karışımları kuru otunun kalite standartları

\begin{tabular}{lccc}
\hline Kalite standard 1 & HP, $\%$ & ADF, \% & NDF, \% \\
\hline En üstün kaliteli & $>19$ & $<31$ & $<40$ \\
1. kalite (çok iyi) & $17-19$ & $31-35$ & $40-46$ \\
2. kalite (iyi) & $14-16$ & $36-40$ & $47-53$ \\
3. kalite (orta) & $11-13$ & $41-42$ & $54-60$ \\
4. kalite (kötü) & $8-10$ & $43-45$ & $61-65$ \\
5. kalite (kabul edilemez) & $<8$ & $>45$ & $>65$ \\
\hline
\end{tabular}

\section{Bulgular ve Tartıșma}

Siirt yöresinde üretilen ve ruminant beslemede yaygın olarak kullanılan buğday samanı kaba yem maddesinin ADF, NDF, HP, P, K, Ca ve Mg oranları Tablo 3 'te verilmiştir.

Kaba yemlerin sindirilebilirliğinin bir göstergesi olan ADF oranı (Gürsoy ve Macit, 2014) buğday samanında \% 46.29-58.69 arasında değişmiş olup, samanın ortalama ADF oranı \% 52.31 olmuştur (Tablo 3). Yemin sindirim derecesinin yüksek olması, o yemin hücre duvarı bileşenlerinin düşük olmasına da bağlıdır. Bu nedenle, kaba yemlerin kalitesi bakımından ADF oranının düşük olması istenir (Van Soest, 1994; Kaya, 2008). Buna göre, Tablo 2'de verilen sınıflama sistemi dikkate alındığında, buğday samanı kaba yeminin "kabul edilemez" kalite derecesine sahip olduğu görülmüştür. Yapılan farklı araştırmalarda buğday samanının ADF içeriklerinin \% 46.8 ile \% 85.0 arasında değiştiği rapor edilmiştir (Can ve ark., 2004; Fluharty, 2009; Kalkan ve Filya, 2011; Avcı ve ark., 2012; Şahan, 2012; Güngör ve ark., 2008; Eser, 2016; Abdi ve Kılıç, 2018).

Bitkideki hücre duvarı bileşenlerinden (selüloz+lignin+hemiselüloz) oluşan NDF oranının ADF'de olduğu gibi düşük olması istenir (Van Soest, 1994; Kaya, 2008; Kutlu, 2008). Bu çalışmada analizi yapılan buğday samanlarının NDF içeriklerinin \% 75.88-89.30 arasında değiştiği belirlenmiştir (Tablo 3). Rohweder ve ark. (1978) tarafindan bildirilen sınıflandırmaya göre (Tablo 2), NDF oranı yönünden de buğday samanlarının "kabul edilemez" kaba yem kalite derecesine sahip olduğunu söylemek mümkündür. Buğday samanının NDF içeriğinin değişik araştırıcılar (Can ve ark., 2004; Kalkan ve Filya, 2011; Avcı ve ark., 2012; Eser, 2016; Abdi ve Kılıç, 2018) tarafından \% 54.43 ile \% 81.73 arasında 
değiştiği bildirilmektedir. Literatürdeki bu değerler genel olarak çalışmamızda saptanan değerlerin altındadır.

Ham protein oranı kaba yemlerin en önemli kalite parametreleri içerisinde yer almaktadır. Tablo 3 'ten de görüleceği üzere, Siirt yöresinde üretilen buğday samanının HP içeriğinin \% 0.24-5.03 arasında değiştiği, ortalama HP oranının \% 2.42 olduğu tespit edilmiştir. Tablo 2'de verilen kalite standardına göre buğday samanı kaba yeminin HP yönünden de "kabul edilemez" kalite derecesine sahip olduğu görülmüştür. Buğday samanı için kuru maddede HP içeriğini Can ve ark. (2004) \% 3.61, Güngör ve ark. (2008) \% 3.63, Kalkan ve Filya (2011) \% 2.10, Eser (2016) \% 3.90 ve Abdi ve Kılıç (2018) \% 2.93 olarak belirlemişlerdir. Önceki çalışmalardaki bu değerlerin araştırmamızdaki değişim aralığı içerisinde olduğu görülmüştür.

Buğday samanının kuru maddesindeki P, K, Ca ve Mg içerikleri sırasıyla \% 0.08-0.22, \% 0.12-1.52, \% 0.10-0.58 ve \% 0.02-0.27 arasında değişim gösterdiği; adı geçen bu makro elementlerin ortalama değerlerinin ise sirasıyla \% $0.17, \% 0.69, \% 0.38$ ve $\% 0.08$ olduğu belirlenmiştir (Tablo 3). Yem rasyonlarında hayvanların $\mathrm{P}, \mathrm{K}, \mathrm{Ca}$ ve $\mathrm{Mg}$ ihtiyacının minimum düzeyde karşılanabilmesi için adı geçen bu makro elementlerin yemlerde sirasıly $\% 0.40, \% 1.0, \% 0.90$ ve $\% 0.25$ oranlarında bulunmas1 gerektiği bildirilmektedir (Anonymous, 2001; Muller, 2009). Bu kritik değerler dikkate alındığında, hayvan beslemede son derece önemli metabolik olaylarda rol oynayan makro elementler $(\mathrm{P}, \mathrm{K}, \mathrm{Ca}, \mathrm{Mg})$ yönünden buğday samanının, ruminantların ihtiyacını karşılamaktan uzak olduğunu söylemek mümkündür.

Tablo 3. Buğday samanına ait bazı besin maddesi içerikleri $(\%)(n=25)$

\begin{tabular}{cccccccc}
\hline Örnek No & ADF & NDF & HP & P & K & Ca & Mg \\
\hline 1 & 56.87 & 88.00 & 1.57 & 0.15 & 0.33 & 0.37 & 0.07 \\
2 & 49.91 & 85.51 & 2.81 & 0.21 & 1.00 & 0.27 & 0.12 \\
3 & 53.24 & 78.95 & 5.03 & 0.20 & 1.03 & 0.37 & 0.09 \\
4 & 58.69 & 87.66 & 2.66 & 0.19 & 0.60 & 0.10 & 0.07 \\
5 & 51.00 & 82.46 & 3.12 & 0.18 & 0.54 & 0.41 & 0.10 \\
6 & 52.51 & 83.28 & 2.25 & 0.17 & 0.54 & 0.48 & 0.09 \\
7 & 49.02 & 80.78 & 2.90 & 0.20 & 0.47 & 0.50 & 0.10 \\
8 & 53.73 & 82.97 & 4.86 & 0.08 & 0.12 & 0.58 & 0.27 \\
9 & 53.99 & 87.85 & 1.90 & 0.18 & 0.79 & 0.48 & 0.05 \\
10 & 46.29 & 75.88 & 3.95 & 0.20 & 0.58 & 0.38 & 0.12 \\
11 & 47.29 & 89.28 & 1.12 & 0.16 & 0.17 & 0.42 & 0.07 \\
12 & 48.29 & 86.81 & 1.82 & 0.16 & 1.13 & 0.34 & 0.06 \\
13 & 49.29 & 89.30 & 0.24 & 0.12 & 0.48 & 0.47 & 0.03 \\
14 & 50.29 & 85.61 & 1.37 & 0.17 & 0.55 & 0.35 & 0.08 \\
15 & 51.29 & 85.15 & 1.78 & 0.22 & 1.52 & 0.36 & 0.07 \\
16 & 52.29 & 85.70 & 1.96 & 0.16 & 0.64 & 0.40 & 0.06 \\
17 & 53.29 & 88.89 & 1.66 & 0.15 & 0.43 & 0.35 & 0.05 \\
18 & 54.29 & 85.48 & 2.33 & 0.19 & 0.75 & 0.42 & 0.06 \\
19 & 55.29 & 83.51 & 2.64 & 0.17 & 0.39 & 0.26 & 0.05 \\
20 & 52.90 & 82.11 & 3.23 & 0.22 & 1.38 & 0.26 & 0.09 \\
21 & 53.84 & 85.00 & 2.69 & 0.18 & 0.95 & 0.33 & 0.04 \\
22 & 58.32 & 86.42 & 0.99 & 0.14 & 0.37 & 0.37 & 0.02 \\
23 & 54.57 & 82.03 & 2.83 & 0.18 & 1.24 & 0.43 & 0.08 \\
24 & 50.49 & 83.39 & 2.52 & 0.18 & 0.69 & 0.36 & 0.11 \\
25 & 50.70 & 83.03 & 2.39 & 0.19 & 0.58 & 0.37 & 0.08 \\
\hline En düşük & 46.29 & 75.88 & 0.24 & 0.08 & 0.12 & 0.10 & 0.02 \\
\hline En yüksek & 58.69 & 89.30 & 5.03 & 0.22 & 1.52 & 0.58 & 0.27 \\
\hline Ortalama & 52.31 & 84.60 & 2.42 & 0.17 & 0.69 & 0.38 & 0.08 \\
\hline & & & & & & &
\end{tabular}

\section{Sonuc}

$\mathrm{Bu}$ araştırmada, hayvansal üretimin kaba yem kaynağını teşkil eden ve Türkiye'nin birçok bölgesinde yaygın olarak kullanılan buğday samanının yem değeri Siirt ili özelinde incelenmiş; araştırma sonucunda, buğday üretim alanlarından elde edilen samanın yem değerinin oldukça düşük olduğu belirlenmiştir. Buğday samanının tek başına kullanılmasının hayvanlarda tokluk hissi vermekten öte gitmeyeceği düşünüldüğünde, samanların kaba yem kalitesini arttırmaya yönelik araştırmalar üzerinde yoğunlaşılmasının yerinde olacağı düşünülmektedir. 


\section{Kaynaklar}

Abdi, A. M., \& Kılıç, Ü. (2018). Farklı samanlarda lignin peroksidaz enzimi kullanımının yem değeri üzerine etkisi. KSÜ Tartm ve Doğa Dergisi, 21(3), 374-384.

Anonim. (2019). Bitkisel Üretim İstatistikleri. Türkiye İstatistik Kurumu, (http://www.tuik.gov.tr/Pre Tablo.do?alt id=1001), Erișim tarihi: 22.11.2019.

Anonymous. (2001). Nutrient Requirements of Dairy Cattle. Seventh Revised Edition. (http://books.nap.edu/openbook.php?record_id=9825\&page=110), Erişim tarihi: 15.11.2019.

Anonymous. (2018). WinISI 4 Calibration Software: Ground, expandable equation packages (http://www.winisi.com/product_calibrations.htm), Erişim tarihi: 20.01.2018.

Avc1, M., Denek, N., \& Kaplan, O. (2012). Çelikhan doğal bitki florasında bulunan geven (Astragalus gummifera) bitkisinin besin değerinin belirlenmesi. Harran Üniversitesi Veteriner Fakakültesi Dergisi, 1(1), 44-46.

Bıçakçı, E., \& Açıkbaş, S. (2018). Bitlis ilindeki kaba yem üretim potansiyelinin hayvan varlı̆̆ına göre yeterliliğinin belirlenmesi. BEÜ Fen Bilimleri Dergisi BEU Journal of Science, 7(1), 180185.

Brogna, N., Pacchioli, M.T., Immovilli, A., Ruozzi, F., Ward, R., \& Formigoni, A. (2009). The use of near-infrared reflectance spectroscopy (NIRS) in the prediction of chemical composition and in vitro neutral detergent fiber (NDF) digestibility of Italian alfalfa hay. Ital. J. Anim. Sci., 8(Suppl. 2), 271-273.

Can, A., Denek, N., \& Yazgan, K. (2004). Effect of urea and molasses supplementation on nutrient intake and digestibility of sheep fed with straw. Journal of Animal Veterinary Advances, 3 (7), $466-469$.

Eser, S. (2016). İnokulant ve enzim ilavesinin farkli samanlarin besleme değeri üzerine etkileri. Namık Kemal Üniversitesi Fen Bilimleri Enstitüsü Zootekni Anabilim Dalı, Yüksek lisans tezi. $39 \mathrm{~s}$.

Fluharty, F. L. (2009). Protein and Energy Supplementation of Crop Residues for Breeding Cattle. Department of Animal Sciences, the Ohio State University. p. 01-05.

Güngör, T., Başalan, M., \& Aydoğan, İ. (2008). Kırıkkale yöresinde üretilen bazı kaba yemlerde besin madde miktarları ve metabolize olabilir enerji düzeylerinin belirlenmesi. Ankara Üniversitesi Veteriner Fakültesi Dergisi, 55, 111-115.

Gürsoy, E., \& Macit, M. (2014). Erzurum ili meralarında doğal olarak yetişen bazı buğdaygil yem bitkilerinin in vitro gaz üretim değerlerinin belirlenmesi. Yüzüncü Yll Üniversitesi Tartm Bilimleri Dergisi, 24(3), 218-227.

Jeroch, H., Flachowsky, G., \& Weissbach, F. (1993). Futtermittelkunde. Gustav Fischer Verlag, Stuttgart.

Kalkan, H., \& Filya, İ. (2011). Sellülaz enziminin buğday samanının besleme değeri, in vitro sindirimi ve mikrobiyal protein üretimi üzerine etkileri. Kafkas Üniversitesi Veteriner Fakültesi Dergisi, 17(4), 585-594.

Kaya, Ş. (2008). Kaba yemlerin değerlendirilmesinde göreceli yem değeri ve göreceli kaba yem kalite indeksi. Türk Bilimsel Derlemeler Dergisi, 1(1), 59-64. 
Kuşvuran, A., Nazlı, R.İ., \& Tansı, V. (2011). Türkiye'de ve Batı Karadeniz Bölgesi'nde çayır-mera alanları, hayvan varlığ 1 ve yem bitkileri tarımının bugünkü durumu. Gaziosmanpaşa Üniversitesi Ziraat Fakültesi Dergisi, 28(2): 21-32.

Kutlu, H. R. (2008). Yem Değerlendirme ve Analiz Yöntemleri. Ders Notu, Çukurova Üniversitesi, Ziraat Fakültesi, Zootekni Bölümü, Adana. (http://www.zootekni.org.tr/upload/File/ sunular/tm.pdf) (Erişim tarihi: 02.12.2019).

Muller, L. D. (2009). Dietary Minerals for Dairy Cows on Pasture. (www.das.psu.edu/ researchextension/ dairy/.../pdf/mineralsforpasture.pdf.), Erişim tarihi: 25.10.2018.

Rohweder, D. A., Barnes, R. F., \& Jorgensen, N. (1978). Proposed hay grading standards based on laboratory analyses for evaluating quality. Journal of Animal Science, 47(3), 747-759.

Şahan, Z. (2012). Bazı bitki uçucu yağlarının enerji, protein ve lif kaynă̆ı yemlerın ın vitro gerçek sindirilebilirliğine ve yüksek verimli süt sığırlarında süt verimi ve süt kompozisyonlarına etkileri. ÇÜ. Fen Bil.Ens. Zootekni ABD, Doktotra Tezi. 147 s.

Özkan, U., \& Şahin Demirbağ, N. (2016). Türkiyede kaliteli kaba yem kaynaklarını mevcut durumu. Türk Bilimsel Derlemeler Dergisi, 9(1), 23-27.

Van Soest, P.J. (1994). Nutritional Ecology of the Ruminant (2nd Ed.), Ithaca, N.Y. Cornell University Press. 